PAEDAGOGIA ChristianA

$1 / 25$ (2010) - ISSN 1505-6872

Marian Nowak

Lublin

\title{
Dialog w wychowaniu
}

Wychowanie jest zjawiskiem rozgrywającym się między ludźmi i istotowo wpisanym w międzyludzką relację. Tego rodzaju relacja znajduje swoje wielorakie formy, wśród których możemy wymienić m.in. "spotkanie» i «dialog». O tym ostatnim chcemy zwłaszcza mówić, odnosząc go do wychowania ${ }^{1}$.

Kategoria «dialogu» wyprowadzana z języka greckiego od słowa lógos (słowo, mowa, wypowiedź) oraz diá (jako zaimek oznaczający przejście przez coś lub ruch, polegający na przechodzeniu z jednego punktu do drugiego) zastosowany tutaj w znaczeniu przeciwnym do monologu, gdy możemy stwierdzić, że jest to ktoś jeden z kimś drugim. Kategoria «dialog» oznacza także ten ruch, który możemy ująć jako wyjście i powrót słowa w relacji między dwu lub więcej rozmówcami, jak też możemy tą kategorią określić samo rozmawianie lub jego znajdowanie. Oczywiście ta analiza etymologiczna nie przybliża nam jeszcze całego bogactwa, jakie zawiera w sobie «dialog» związany z życiem człowieka w swoim dogłębnym i istotnym znaczeniu.

Artykuł stawia sobie za cel przybliżenie się do tego właśnie bogactwa i tej istoty dialogu, które chcemy odkrywać w rzeczywistości wychowawczej. Chociaż o dialogu i jego obecności w wychowaniu możemy mówić już od czasów starożytności, to zwłaszcza powinniśmy wziąć pod uwagę okres

* Ks. prof. dr hab. Marian Nowak, prodziekan Wydziału Nauk Społecznych Katolickiego Uniwersytetu Lubelskiego Jana Pawła II.

${ }^{1}$ Zob. H. Henz, Lehrbuch der systematischen Pädagogik. Allgemeine und differentielle Erziehungswissenschaft. Einführung in die pädagogischen Forschungsmethoden, Freiburg - Basel - Wien 1964, s. 125. 
ostatniego stulecia. Na grunt pedagogiki problematykę dialogu wprowadził i przyczynił się do jej umocnienia się w niej filozof, teolog i pedagog żydowski Martin Buber (1878-1965)². Nade wszystko to w związku z jego osobą należy podkreślić szczególne pogłębienie problematyki dialogu w początkach XX wieku, także zwłaszcza dzięki filozofii egzystencjalizmu, a jeszcze bardziej filozofii «Ja-Ty» Martina Bubera. Nie dokonało się to oczywiście bez dużego wpływu także na pedagogikę i dydaktykę, a zwłaszcza wzbogaciło istotną w nich problematykę metodyczną, czy nawet wręcz przyczyniło się do rozwoju technologii i strategii wychowania i nauczania.

W tym kontekście, jako swoistą kontynuację tej problematyki, możemy dostrzegać rozwój, również na polskim gruncie, całkowicie oryginalnej, a jednocześnie związanej z filozoficznym myśleniem personalno-egzystencjalnym - «pedagogiki dialogu» ks. Janusza Tarnowskiego.

W tym układzie problemowym zwrócimy uwagę na odczytanie najpierw samej natury dialogu w ogóle, a nade wszystko jego istoty w wychowaniu, następnie podejmiemy analizę poszczególnych elementów tworzących strukturę procesu dialogu oraz jego uwarunkowania, jak również wskażemy na odmiany dialogu, a wreszcie na jego implikacje dla wychowania i nauczania oraz dla samej pedagogiki jako nauki.

\section{Natura $i$ istota dialogu $w$ wychowaniu}

Współczesny język pedagogiczny określa często «relację: wychowawca-wychowanek» jako «dialogiczną» - a nawet wręcz dochodzi on aż do sformułowania oryginalnej koncepcji pedagogicznej określanej jako «pedagogika dialogu» ${ }^{3}$.

Sam dialog jest związany z różnicami w percepcji świata i siebie, na którą składają się nasze wrażenia, nasza indywidualna i zbiorowa historia, nasze dążenia i charakter. Ich zróżnicowanie owocuje różnicami w percepcji rzeczywistości, co wymaga podzielenia się własnymi ideałami i własną percepcją rzeczywistości, jak również ubogacenia się percepcją innych. Wymaga to postawienia i poddania konfrontacji naszych odmiennych punktów patrzenia, wysiłku wzajemnej integracji oraz wzajemnej nieodzowności w zrozumieniu jakiegoś problemu lub złożonej rzeczywistości - a zatem dojścia do pewnej współistniejącej współobecności wielu perspektyw patrzenia.

2 A. Wawrzyniak, Martin Buber, w: Encyklopedia Katolicka, t. 2, Lublin 1976, kol. $1141-1144$.

${ }^{3}$ Zob. J. Tarnowski, Pedagogika dialogu, w: B. Śliwerski (red.), Edukacja alternatywna Dylematy teorii i praktyki, Kraków 1992, s. 112-122. 
Jak już podkreślano, początki koncepcyjnych ujęć pedagogiki dialogu możemy wyprowadzać z odległej przeszłości, sięgającej m.in. Dialogów Platońskich - jako formy prowadzenia rozmowy w procesie nauczania. $\mathrm{W}$ istocie bowiem relacja dialogu u swoich początków wywodzi się z działalności dydaktycznej i dopiero w następnej kolejności możemy widzieć jej zadomowienie się $\mathrm{w}$ związku z wychowaniem. W wychowaniu jednakże dialog wiąże się również ze spotkaniem się dwóch osób w celach realizacji pewnej wspólnej pracy umysłowej. Umysły ludzkie, przez wymianę i dyskusję, stają się bardziej aktywne i osiągają efekty bardziej pogłębione swojego namysłu. Tego rodzaju spotkania ze swojej natury są dialogiem, a gdy się on już zacznie realizować, powstaje największa stymulacja i duchowe ubogacenie wychowanka, który dochodzi, wraz ze swoimi siłami, do optymalnych wyników umysłu i nabywa bardziej solidnej i pogłębionej wiedzy ${ }^{4}$.

Możemy podkreślić na wstępie, że proces nauczania, jak i wszelkiego kształcenia, powinien być dialogiczny i to w sensie najbardziej istotowym. Nie wyklucza to faktu, że pewne prezentacje monologiczne nie miałyby być także możliwe i faktycznie mogą one mieć miejsce, jako efekty dialogu ucznia z samym sobą, zachodzącego w uczniu - wewnętrznie. Również nie oznacza to, że i sam nauczyciel nie mógłby oddziaływać swoim autorytetem. Jednakże podstawowa metoda nauczania, dla wzbudzenia aktywności wychowanka i ucznia oraz pobudzenia go do osobowego rozwoju, powinna posiadać u swoich podstaw - i w swojej istocie zawsze posiada - charakter dialogicznys.

Dialog polega na wymianie słów między osobami, ale rodzi się on $\mathrm{z}$ aktywnego słuchania swego rozmówcy, z zachowaniem pewnych zasad, m.in. chociażby bez przerywania mówiącemu i wpadania mu w słowo. Wymaga on jednakże wielu więcej postaw i wewnętrznych także nastawień i sprawności. Życzliwe spojrzenie na drugiego człowieka, skierowany do niego uśmiech, bezinteresowna pomoc - to pierwsze kroki do nawiązania właściwego międzyludzkiego dialogu.

Dialog jest rozumiany jako wyjście «ja» od samego siebie przez mowę (słowami lub gestami) i przez nią podążanie ku drugiemu «ty», w którym darujemy się jemu, a z drugiej strony przyjmujemy jego słowo, a przez nie otwieramy się na najgłębszą jego intymność. Dynamikę dialogu można także rozważać i realizować w kierunku odwrotnym, tzn. wychodząc od «ty» i zmierzając ku «ja». W każdym przypadku widzimy w sensie symbolicznym, jakie są podstawowe cechy charakteryzujące i zarazem warunkujące autentyczny dialog. Do takich zaś uwarunkowań zalicza się posiadanie wy-

\footnotetext{
${ }^{4}$ Zob. G. Nosengo (a cura di), La persona umana e l'educazione, Brescia 2006, s. 149.

5 Tamże.
} 
raźnej świadomości własnej tożsamości, ale także świadomości własnych ograniczeń, czy też pełne ufności otwarcie na drugiego, zdolność «darowania siebie» i wzajemnie - również «przyjęcie drugiego» ${ }^{6}$.

W wychowaniu, które jest procesem związanym nie tylko ze wzrostem i rozwojem, ale także procesem komunikowania i międzyludzkich relacji, dialog staje się bardzo ważny. Jednocześnie dialog, podobnie jak wychowanie, jest szczególną umiejętnością, wielką sztuką, a także ważnym czynnikiem wychowania. $\mathrm{W}$ dialogu istnieje i powstaje prawdziwa szansa na wzajemne odkrywanie siebie i otaczającej nas rzeczywistości.

Tak postrzegany dialog jest pewną możnościa, a nawet wręcz koniecznością, jeśli chodzi o formowanie swojej tożsamości podmiotowej, kształtowanie relacji interpersonalnych i wspólnotowych form w życiu społecznym chodzi o formowanie autentycznej wspólnoty. Ten ostatni wymiar wydaje się być dość zaniedbany w opracowaniach podejmujących problematykę dialogu, a przecież to właśnie tutaj odsłania się rzecz szczególnej wagi, zwłaszcza jeżeli zważymy na fakt samej natury człowieka, która jest nie tylko indywidualna, ale i społeczna. Dialog społeczny między poszczególnymi grupami, mający na celu doprowadzenie do wzajemnych relacji aż do wspólnotowości i zbiorowej zgodności, co do jej rozumienia, jest zwykle efektem wielorakich debat, konwersacji, kontrowersji, dyskusji i dialogu w ramach całej społeczności.

Odpowiednio do ujęcia natury człowieka, możemy mówić o głęboko przecież wpisanym w samą naturę człowieka - dialogu, jako posiadającym wymiar nie tylko indywidualny, ale i społeczny. Tak ujmując dialog, możemy stwierdzić, że poza dialogiem interpersonalnym (i dialogiem wewnętrznym z samym soba), należałoby pomyśleć i wzmóc prace właśnie nad dialogiem społecznym, kulturalnym, politycznym, religijnym, a także i nad tym bardzo specyficznym dialogiem - jakim jest dialog kościelny. Każdy z nich posiada własne konotacje i własności zarówno te wspólne z innymi, jak i te całkowicie specyficzne.

$\mathrm{W}$ procesie dialogu wychodzimy zatem z tego stanowiska, że dwie osoby wkraczają w relację natury duchowej, w której wyłania się najpierw pewien znak, na który następnie udzielana jest odpowiedź, jest tam zatem «moment zawołania» $\mathrm{i}$ «moment odpowiedzi», wyłania się pewien problem i jest jego rozwiązanie. W wyniku dialogu własne przemyślenia i idee stają się ponadindywidualne, uczucia przybierają postać wyrażoną i podzielaną przez innych, rzeczy otaczające stają się wspólnie analizowane i kontemplowane ${ }^{7}$.

${ }^{6}$ Zob. L. A. Gallo, Dialogo, w: J. M. Prellezo (coord.), Dizionario di scienze dell'educazione, Torino 1997, s. 288.

7 Zob. tamże, s. 288. 
Dialog pozwala nam lepiej zrozumieć siebie, doświadczyć niepowtarzalności, oryginalności i ważności swego głosu oraz pozostawać w otwartości na głos innych, podejmować dialog z młodzieżą i z innymi; dialog jest też próbą obserwacji, także samoobserwacji, dokonywanych zwłaszcza na przykład razem przez pracowników naukowych i studentów, wreszcie tworzy on akademicką i dydaktyczną atmosferę

Ponieważ każdy człowiek daną rzecz czy rzeczywistość widzi inaczej, tym bardziej we wzajemnym komunikowaniu się, dialog jest szczególną drogą przybliżania swoich punktów widzenia i wypracowywania wspólnego ich rozumienia. Poszanowanie odmienności każdego człowieka, jego godności, budzi respekt dla cudzego, czasami innego zdania, ale jest też warunkiem odkrycia prawdy. Udzielenie pomocy wychowankowi w odkryciu prawdy za pomocą dialogu jest zadaniem, któremu powinna towarzyszyć wzajemna chęć rozmawiania i wzajemnego słuchania.

To właśnie w takim kontekście i w procesie dialogu odsłaniają się tajemnice ludzkiego życia, a same dialogi muszą wybrzmieć, aby mógł zaistnieć zharmonizowany i w pełni uzgodniony ich finał czy też ich efekt. Jeśli natomiast do takiego efektu nie zdołalibyśmy dotrzeć, pozostałby jakiś jedynie rys lub dokonałoby się jakieś nie w pełni zadawalające i niewystarczające zamknięcie czegoś. Dialog wymaga także pewnego estetycznego formatu i jest on zawsze wręcz estetyczny. To tutaj tkwiłby podstawowy powód i też z tego względu, w dialogu tkwiłaby ta szczególna relacja między dialogiem a prawdą która sprawia, że pewne niewygodne prawdy (ze względu na przykład na dobro drugiego i miłość ku niemu) nie są podejmowane, lecz jakby ofiarowane na konto niesprawiania bólu partnerowi dialogu - jak pouczał o tym św. Paweł, iż należy „Czynić prawdę w miłości” (Ef 4, 15).

\section{Cechy, formy i modele oraz elementy struktury dialogu}

Jedną z pierwszych postaci dialogu znajdujemy w odległej przeszłości - u Sokratesa, stosującego dialog w swoim nauczaniu, a którego model jest powtarzany w szeregu opracowań pedagogicznych i filozoficznych aż do naszych czasów.

W modelu dialogu Sokratejskiego w istocie wyróżniamy dwie jego formy: pierwsza to «ironia», druga zaś to maièutyka. W związku z pierwszą formą poddawana jest krytyce pycha poznawcza, polegająca na przekonaniu, że wie się wszystko, a której Sokrates przeciwstawiał swoje „wiem, że nic nie wiem"; w drugiej zaś formie wskazuje się na odkrywanie prawdy,

\footnotetext{
${ }^{8}$ Zob. D. Jankowska (red.), W akademickiej przestrzeni dialogu, Warszawa 2009.
} 
a nie zdobywanie jej, gdyż prawda jest dana i odnajdywana wewnątrz duszy ludzkiej, a człowiek w pewnym sensie ją rodzi - z samego siebie niejako wydobywa (maieutyka).

Tak ujęte formy dialogu wskazują, że dialog może przybierać postać także «monologu», tzn. dialogu rozgrywającego się wewnątrz nas samych, gdyż to w nas samych rozgrywają się i «dialogują ze sobą» nasze sądy, wątpliwości, problemy, zapytania, na które musimy, lub na które chcemy udzielić odpowiedzi nie tylko w sensie teoretycznym, ale także w przełożeniu ich na realizację w praktyce?

Na tę właśnie postać «dialogu» - jako «monologu» - zwracał uwage św. Augustyn, interpretując go zresztą w linii «Sokratejskiej maieutyki» realizowanej po chrześcijańsku. $\mathrm{W}$ tym sensie wskazuje na prawdę wpisaną w wewnętrznego człowieka: jeśli człowiek został stworzony na obraz i podobieństwo Boga, nie może nie odnaleźć tej samej prawdy w sobie (dialogując z samym sobą) $)^{10}$.

E. Mounier podkreślał, że już nasze własne myślenie jest dialogiczne. Podkreślał on między innymi: „Nigdy nie myślimy samotnie. Myślenie wewnątrz nas samych dialoguje z wirtualną osobistością, która kwestionuje, zaprzecza lub dręczy w prowadzeniu akcji" ${ }^{11}$.

Z dialogiem wiąże się zwykle konfrontowanie różnych opinii, aby dojść do stanowiska, które je wyrównuje i doprowadza do współbrzmienia. $\mathrm{Z}$ tych też powodów często wiązano dialog $\mathrm{z}$ dialektyka, rozumianą jako «sztuka prowadzenia rozmowy» (Schleiermacher) ${ }^{12}$, chociaż warto podkreślić odmienne ich rozumienie, które w kręgu języka niemieckiego owocuje odmiennymi kategoriami. Mamy tam bowiem «dialektykę» (die Dialektik) oraz «dialogikę» (die Dialogik) ${ }^{13}$.

Dialog w rozumieniu ks. J. Tarnowskiego to nie tylko rozmowa. Przyjęta przez Naszego Autora definicja dialogu określa go jako proces, przez który dwa podmioty używają słowa w zamiarze tego, co każdy z nich myśli i czym żyje, oraz dzięki któremu obaj dochodzą w pewnej mierze do zbliżenia wzajemnego swoich punktów widzenia i właściwego sobie sposobu bycia $^{14}$. Dialog jest tu rozumiany jako: «metoda», «proces» $\mathrm{i}$ «postawa»:

${ }^{9}$ G. Flores d'Arcais, Dialogo, w: tenże (a cura di), Nuovo Dizionario di Pedagogia, Torino 1987, s. 324-325.

${ }^{10}$ Tamże, s. 325-326.

${ }^{11}$ E. Mounier, Traitédu caracter, Paris 1947, s. 661.

${ }^{12}$ F. W. Korn, Wissenschaftstheorie für Pädagogen, München - Basel 1999, s. 232.

${ }^{13}$ Tamże, s. 235.

${ }^{14}$ M. Navratil,Dialogue, w: Vocabulaire de Psychopedagogie et de Psychiatrie del'enfant, Paris 1963, s. 174; J. Guiton, Dialogi z Pawtem VI, Poznań-Warszawa 1969, s. 180n; O. D. Pire, Co to jest dialog?, „Przewodnik Katolicki” 50 (1966), s. 452. 
- «metodą dialogu»ks. Tarnowski określa taki sposób komunikacji, w którym dwa podmioty dążą do wzajemnego zrozumienia, zbliżenia się oraz do współdziałania. Jak zauważa, w metodzie ujawniają się trzy sfery ludzkiej psychiki: poznawcza, emocjonalna i prakseologiczna (działaniowa). Pojmując «dialog» jako «metodę», ks. Tarnowski określa dialogiem sposób komunikacji między ludźmi, w którym rozmawiają oni ze sobą (lub używają do tego celu innych środków) w celu wzajemnego zrozumienia się, zbliżenia i współdziałania;

- «proces dialogu» zachodzi wtedy, gdy chociażby jeden z elementów zawartych w metodzie został uwzględniony. Mamy do czynienia zatem z procesem dialogowym, gdy ów potrójny cel został przynajmniej w pewnej mierze osiagnięty, to znaczy, gdy przynajmniej jedna z płaszczyzn komunikacji interpersonalnej stała się wspólna dla partnerów;

- «postawa dialogu» „to gotowość otwierania się na rozumienie, zbliżenie się i współdziałanie (w miarę możności) w stosunku do otoczenia"15. Postawa dialogowa polega na stałej gotowości do dążenia przez rozmowę lub inne środki do zrozumienia innych ludzi, zbliżenia się do nich i w miarę możności współdziałania $\mathrm{z}$ nimi ${ }^{16}$.

Relacja: wychowawca-wychowanek z pozoru może być określana jako jednostronna, ale jeżeli ma się na uwadze strukturę procesu wychowania dialogowego, można stwierdzić, że ta relacja przebiega właśnie i zawsze w formie dialogowej ${ }^{17}$.

Każda rzeczywistość posiada jakieś swoje cechy i elementy ją konstytuujące. Jakie byłyby zatem elementy konstytuujące dialog w wychowaniu?

Możemy te elementy konstytuujące dialog wiązać z podmiotami relacji i ich wzajemnym układem, bądź aspektami dialogu czy też jego treściami.

Biorąc natomiast pod uwagę relacje podmiotów i ich rolę także w procesie dialogowania, możemy mówić, analogicznie do koncepcji wychowania i nauczania, o dialogu, który akcentuje bądź to aktywność wychowawcy, bądź wychowanka, bądź innych jeszcze okoliczności - na przykład techniki. Możemy zatem te koncepcje opisać jako:

1) «magistrocentryzm» (z eksponowaniem aktywności nauczyciela);

2) «puerocentryzm» («pajdocentryzm» $z$ aktywnością wychowanka

${ }^{15}$ J. Tarnowski, Problem chrześcijańskiej pedagogiki egzystencjalnej, Warszawa 1982, s. 258 .

${ }^{16}$ Tenże, Próby dialogu z młodymi. Prekatecheza egzystencjalna, Katowice 1983, s. $342-343$.

${ }^{17}$ Tamże, s. 197. 
i ucznia) lub też «socjocentryzm» (z aktywnością zespołu wychowanków i uczniów);

3) «technocentryzm» (z zastosowaniem technik, czy w ogóle techniki i jej wytworów w ramach technologii dialogowania) ${ }^{18}$.

Warto bliżej opisać każdą z tych koncepcji:

Ad. 1) «Magistrocentryzm» - w tej koncepcji głównym działającym w dialogu jest wychowawca i nauczyciel, który przekazuje wiedzę oraz kulturę, wpisując uczniów w istniejącą tradycję pedagogiczną, społeczna, kulturową. Wiodącą rolę w kreowaniu całego systemu dialogowania w szkole i w instytucjach wychowawczych odgrywają nauczyciele i wychowawcy. W tej koncepcji dominują wartości lub po prostu treści przekazywane. Sam wychowanek natomiast wypełnia swoje zadania, gdy przyjmie postawę przyjmowania i zapamiętywania, czy też wykazania się wiedza, gdy zostanie postawiony wobec jakiejś formy sprawdzania efektów tego nauczania. Będzie mógł wykazać się aktywnością dopiero kiedyś, gdy podejmie już po ukończeniu szkoły odpowiedzialne funkcje i zadania w życiu społecznym, w kulturze czy w świecie pracy zawodowej. W samej zaś szkole jego główne zadanie sprowadza się do przyjmowania i otrzymywania ${ }^{19}$.

Ad. 2) «Puerocentryzm» («paidocentrym») i «socjocentryzm»- te koncepcje dialogu akcentują wprawdzie aktywność wychowanka i ucznia w wymiarze bądź to indywidualnym (w przypadku puerocentryzmu - pajdocentryzmu) czy też w wymiarze kolektywnym, zbiorowym (w przypadku socjocentryzmu), ale czyż nie są to przeważnie postulaty aktywności nad biernością ucznia? Szczególnie kładzie się tutaj akcent na rolę wewnętrznej dynamiki jednostki: w wychowaniu chodzi o budzenie zainteresowań, pobudzanie i dostosowanie się do potrzeb dziecka. Należy pozwolić wychowankowi czy też uczniowi na dokonywanie autonomicznych odkryć, chociażby to było złączone z mozolnym procesem uczenia się metodą prób i błędów. W ramach akcentowania roli wewnętrznej dynamiki jednostki wskazuje się między innymi:

- na niektóre konkretne propozycje teoretycznych ujęć w postaci «percepcjonizmu» ze szczególnym akcentowaniem roli samej aktywności sensorycznej dziecka rozbudzanej przez - bogatego (pod względem zmysłowego odbioru) otoczenia miejsca wychowania i nauczania system dzwonków, kolorowych mebli i wielorakich bodźców wpływających i ożywiających percepcję zmysłową wychowanka i ucznia - jak chciała tego M. Montessori ${ }^{20}$;

${ }^{18}$ Zob. L. Not, Les grands courants de la pédagogie contemporaine, w: tenże (red.), La pédagogie contemporaine, Paris 1999, s. 11-34.

${ }^{19}$ Zob. tamże, s. 12-14.

${ }^{20}$ Zob. tamże, s. 14-15. 
- na «pragmatyzm» z wyakcentowaniem roli doświadczeń osobistych ucznia i wychowanka czy też w ogóle wyakcentowaniem poznawczej roli doświadczenia (jak chciał tego J. Dewey czy W. James) ${ }^{21}$.

Z kolei podejścia eksponujące i akcentujące «życie społeczne» i ujmujące «podmiotowość wychowanka» w dialogu w kategoriach społecznych, z akcentem zwłaszcza na społeczeństwo, zdają się szczególnie uprzywilejowywać centralną rolę grupy społecznej i jej inicjatyw - rzekomo najbardziej istotnych w dialogu szkolnym czy społecznym. Tego rodzaju stanowiska wyłoniły się w obliczu zauważanych wielkich szkód spowodowanych przez indywidualizm czy też przez koncentrowanie się na spontanicznych poczynaniach samego wychowanka. Zdaniem zwolenników takiego podejścia, należałoby szczególnie eksponować i wspomagać relacje społeczne. Mamy tutaj zatem do czynienia ze wspomaganiem i koncentracją uwagi też raczej na jednym z partnerów dialogu - na wychowanku, rozumianym w kategoriach społecznych, zbiorowych i kolektywnych ${ }^{22}$.

Ad. 3) «Technocentryzm»-wraz z postępem technicznym i rozwojem psychologii czy również socjologii rozwijają się zainteresowania technikami (psychotechniki i socjotechniki), jak i w sensie szerszym samą techniką oraz perspektywą technologiczną, przyjmowaną jako istotna w dialogu - także tym towarzyszącym nauczaniu i wychowaniu, prowadząc do stanowiska technocentryzmu i owocując zainteresowaniem się zastosowaniem technologii, maszyn nauczających i cybernetyzacją pracy szkoły. Coraz bardziej akcent w takiej koncepcji dialogu przesuwa się z osób na konkretne przedmioty, rzeczy i roboty, maszyny nauczające i komputeryzację, widzianą jako podstawowy warunek i przyczynek do powstania efektywnego procesu dialogu - także w nauczaniu czy wychowaniu oraz odpowiedzi na wyzwania edukacyjne współczesności ${ }^{23}$.

Hasła takie jak: „komputeryzacja każdej szkoły”, „komputer w wyposażeniu każdego ucznia", itp. zdają się stanowić przepis na sukces szkoły, cudowne niemal lekarstwo na uzdrowienie całego systemu szkolnego i drogę podniesienia jakości edukacji na naprawdę wysoki i odpowiedni poziom. Uwaga całego społeczeństwa, jak i podmiotów szkoły zdaje się tutaj spoczywać na wyposażeniu szkół jako gwarancji optymalnego dialogu.

Podejmując ocenę tych koncepcji pod względem cech najbardziej je charakteryzujących, możemy stwierdzić, że dialog opisany w postaci magistrocentryzmu charakteryzuje relacja, którą istotowo oddaje zwracanie się podmiotów do siebie w drugiej osobie liczby pojedynczej i mnogiej. Wy-

21 Tamże, s. 15-16.

${ }^{22}$ Zob. tamże, s. 14-17.

${ }^{23}$ Zob. tamże, s. 17-25. 
chowanek i uczeń jest traktowany przedmiotowo, jako obiekt oddziaływań nauczyciela i szkoły. Relacja przybiera postać relacji typu: TY - WY.

Koncepcję dialogu w pajdocentryzmie charakteryzuje nastawienie na relację $\mathbf{w}$ pierwszej osobie liczby pojedynczej i mnogiej (w socjocentryzmie) z wykluczeniem pryncypialnych interwencji nauczyciela. Jest to relacja typu: JA - MY. Jako szczególnych reprezentantów takiego stanowiska możemy wymienić tzw. nowe szkoły, nowe wychowanie, czy w ogóle «szkoły aktywne». Pozostaje również pytanie, stawiane kiedyś przez S. Hessena: skąd miałyby się wziąć te kategorie jak JA, MY w uczniu czy w grupie uczniów? Czy nie czasami przez wcześniejszą i aktualną (tylko bardziej zakamuflowana) aktywność wychowawcy nad biernością wychowanka?

W przypadku zaś koncepcji dialogu w technocentryzmie możemy mówić o jakiejś próbie relacji w trzeciej osobie liczby pojedynczej i mnogiej, w relacjach nieosobowych typu: ON - ONI, jak to często ma miejsce chociażby w dialogu z maszyną lub z oprogramowaniem komputera.

Ogólnie możemy stwierdzić, że wszystkie te koncepcje i zarazem modele dialogu sugerują jednostronność relacji i wnoszą wołanie o potrzebę interakcji, której faktycznie w wyżej przedstawionych modelach brakuje. Jeśli wychowanie i nauczanie będziemy interpretowali w perspektywie relacji międzyludzkich i relacji między sobą poszczególnych podmiotów szkoły, to w tym przypadku nie mielibyśmy chyba w ogóle do czynienia z nauczaniem i wychowaniem, gdyż jednostronne i nierelacyjne ujęcia bardziej przypominają tresurę i kierowanie czy też zostawianie wychowanka samemu sobie, aniżeli jakiekolwiek formy wzajemnego ubogacania się podmiotów szkoły $^{24}$.

W tym też kontekście szczególnego znaczenia nabiera pedagogika relacji, dialogu i spotkania - wnoszona wraz z nurtem egzystencjalizmu, a tak wydatnie podjęta i rozwijana przez «pedagogikę personalistyczną» czy zwłaszcza tę jej odmianę, którą określam jako «pedagogika otwarta».

Dla bliższego natomiast poznania i pogłębienia tych analiz sięgnijmy do opisu struktury procesu dialogu, w którym wyróżniamy sygnalizowaną już wyżej zdolność «bycia w sobie samym» i podstawowego doświadczania swojej tożsamości połączonej z odwagą bycia właśnie takim - i to bycia takim wśród innych, a z drugiej strony chodzi przecież o zdolność otwarcia się na innego - aż do autentycznie wspólnotowego wyjścia ku drugim lub drugiemu i przyjęcia go takim, jakim jest.

Takie rozumienie dialogu pozwala na uniknięcie wieloznaczności, jakiej nabrało to słowo. Możemy również, dla pogłębienia tej problematyki, wskazywać na wielorakie elementy i aspekty, także na bazie powyższych

${ }^{24}$ Zob. tamże, s. 27-31. 
wyróżnień koncepcyjnych, wśród których na szczególną uwagę zasługują między innymi takie aspekty jak:

1) «aspekt osobisty» - prawdziwy dialog jest możliwy pomiędzy dwiema osobami, które mówią i przyjmuja, myślą i rozumieja, wyrażają i mogą przyjąć oraz są właśnie osobami;

2) «aspekt wzajemności» - jednostronnym jest zwiastowanie i oznajmianie czegoś, wykład i przekaz - to nie jest dialog. W dialogu obaj partnerzy są włączeni i powstaje komunikacja miedzy obu biegunami/partnerami;

3) «aspekt postępu i przemiany» sprawiający, że partnerzy dialogu, mówiąc do siebie, wzajemnie się ubogacają i ciagle ze swoistą nowością swojego spojrzenia się odznaczają. Dialog wywołuje i przyczynia się do duchowego rozwoju obu partnerów;

4) «aspekt wstępujący» - jest to taki rodzaj wzrostu, który wywołuje w partnerach dialogu dążenie do postępu i doskonalenia się przez osiaganie wyższych form i wartości;

5) «aspekt formalny» - dialog wymaga minimum formy, w związku właśnie ze swoim ukierunkowaniem na estetykę, aby nie ulec niebezpiecznym prowokacjom i nieodpowiednim trendom natury teoretycznej lub ideologicznej ${ }^{25}$.

Zgodnie jednak z problematyką naszego opracowania stajemy wobec problemu: Jak teraz dialog odnieść do wychowania? Jaką rolę może on spełniać w wychowaniu? Co może oznaczać zatem, że wychowawca i wychowanek są w relacji dialogu?

Zacznijmy od tego, że wychowanek nie jest po prostu materiałem do obróbki, lecz osobą, podmiotem, który wyraża się, mówi, myśli, kocha i ma wiele do przekazania, nawet gdy jest dzieckiem lub młodym człowiekiem jest on po prostu innym. Stąd wyłania się wzajemność relacji, a mianowicie matka kocha dziecko, dziecko kocha matkę, uczeń jest otwarty i ufa swojemu nauczycielowi, ale także nauczyciel jest otwarty i ufa swoim uczniom.

Można zatem mówić, także w sytuacjach szkolnych czy instytucjonalnych wychowania o «dialogu między wychowankiem a wychowawcą» $i$ to w pełnym tego słowa znaczeniu.

\section{Uwarunkowania dialogu w wychowaniu}

Podstawowym warunkiem dialogu staje się, jak o tym była mowa w związku ze strukturą dialogu, specyficzna zdolność do bycia w sobie (swoista samotność) oraz zdolność wchodzenia w autentyczne relacje spo-

${ }^{25}$ Zob. H. Henz, dz. cyt., s. 126. 
łeczne - zdolność budowania wspólnoty. Tego rodzaju zdolność wymaga też wychowania.

Wychowanie do samotności wskazuje na potrzebę i zdolność wejścia we własne «ja», wymaga rozważenia nad wielorakimi doświadczeniami spotkań z innymi ludźmi i wydarzeniami. Odnosząc się do aktualnych uwarunkowań, możemy stwierdzić, że człowiek współczesny nie jest przyzwyczajony do samotności, do swoistego wyciszenia się celem nabrania także sił do działania i współdziałania z innymi. Raczej podkreśla się zbytni aktywizm współczesnych, oderwany najczęściej od pogłębionej refleksji i wyzuty z uczuć.

Tymczasem to właśnie dzięki doświadczeniu samotności staje się możliwe odkrywanie wartości samego siebie i innych. W zgiełku natomiast zatracamy i siebie i gubimy właściwe relacje $\mathrm{z}$ innymi, łatwo stając się po prostu jednostką w thumie.

Wychowywać do przyjęcia własnej tożsamości - w sposób szczególny zostało to zauważone i było eksponowane przez S. Kierkegaarda i egzystencjalistów i było wyrażane między innymi przez kategorię «autentyzmu». W tym sensie N. Abbagnano pisat:

Wyizolowanie się od innych nie jest samotnością. Ta ostatnia bowiem jest wybierana i chciana ze względu na jakiś cel, dla osiągnięcia którego nie izolujemy się tak zwyczajnie od innych, lecz poszukujemy wyższych form komunikowania się z nimi (inaczej prywatność, zdystansowanie, to po prostu respektowanie wolności innych i jest przeciwieństwem plotkarstwa). Wyizolowanie się powodowane przesądami jest zwykłym rasizmem, nacjonalizmem, itp. Wyizolowanie ma miejsce także w wypadku matki zbyt pobłażliwej wobec dziecka. Izolowanie się od innych jest bardzo propagowane przez cywilizację przemysłowa, czyniącą powierzchownymi wszelkie kontakty między ludźmi ${ }^{26}$.

Samotność natomiast, jaką mamy na uwadze, nie prowadzi do wyizolowania, lecz stanowi swoisty regulator naszych relacji z innymi. Jest ona związana ze skupieniem medytacyjnym, które mogą podejmować istoty zanurzone w rzeczywistości - jak zwykł był mawiać Paulo Freire ${ }^{27}$.

Samotność w swoim znaczeniu antyindywidualistycznym jest podstawowym warunkiem prawdziwego dialogu, uzdalniając do rozmawiania z samym sobą i z Bogiem. To dialog wewnętrzny z samym sobą umożliwia poznawanie miłości do innych, w których odkrywamy własne lęki i tę samą istotę. Tego rodzaju dialog wewnętrzny jest współzależny od dialogu

\footnotetext{
${ }^{26}$ N. Abbagnano, Problemi di sociologia, Torino, 1959, s. 152.

${ }^{27}$ P. Freire, La pedagogia degli opressi, Milano 1973.
} 
zewnętrznego, a zdaniem H. Bon, dialog z innymi umożliwia i warunkuje dialog z samym sobą ${ }^{28}$.

Uczymy się też ufania innym, nadziei związanej z ostatecznym celem ludzkości, przyswajamy sobie to myślenie krytyczne, które czyni nas zdolnymi do przyjęcia sposobu myślenia innych jako podstawy ubogacania się, a nie jako jakiejś opozycji potocznej i niezbyt dojrzałej w stosunku do naszego stanowiska ${ }^{29}$.

Wychowanek wychowany do samotności, która nie jest izolowaniem się od świata i jego problemów, staje się dyspozycyjny do dialogu z innymi, włączając $w$ ten dialog właśnie świat i jego niepokoje, jakie zdają się przybierać na sile. Stąd ważnym, wręcz podstawowym zadaniem szkoły i w ogóle naglącym zadaniem wychowania, staje się dzisiaj wychowanie do samotności, jako związane z wprowadzeniem do refleksji i do konfrontowania się z wydarzeniami życia w kontekście społecznym.

Gdzie natomiast brakuje dialogu, nie ma też wspólnoty, brakuje tych wartości, które związane są z emocjami człowieka: wiarą, poszanowaniem wspólnego dziedzictwa, patriotyzmem, ideałami i nadziejami. Oczywiście, mamy na uwadze dialog nie tyle, jako rozmawianie ze soba, lecz dialog prawdziwy, autentyczny, polegający owszem na mówieniu, ale też na rozumieniu się i swoistej więzi, jaka w trakcie tej rozmowy powstaje. W takiej rozmowie poza wszystkimi innymi okolicznościami nieodzowna staje się umiejętność odpowiedniego dawania i otrzymywania.

Współcześnie ludzie lubią wprawdzie dyskutować, ale czy potrafią oni dyskutować? Postawiony problem jest bardzo istotny, zwłaszcza gdy uwzględnimy aktualny obyczaj dyskutowania, jaki jest nam prezentowany w mediach czy także w polityce. Wydaje się też, że wielkie zaniedbania w tym względzie powinny odnotować po swojej stronie szkoły kształcące dziennikarzy i polityków, a także ogólny klimat życia.

Wprawdzie w pewnych grupach czy nawet koalicjach partyjnych w wyniku dyskusji może dochodzić do pewnych uzgodnień co do wspólnej realizacji jakichś celów i moga pojawić się nawet jakieś ustalenia (np. w ramach instytucji usiłujących funkcjonować demokratycznie), ale zwłaszcza czas - i to na ogół dość krótki - obnaża, jak takie dyskutowanie jest lub było puste i mało przydatne. Te ułomności zwykle są powodowane tym, że w postawach samych dyskutantów brakuje jakiejkolwiek intencji wysłuchania innego i przyjęcia jego sposobu widzenia, jako przynajmniej do rozważenia, lecz dominuje podsycana dodatkowo jeszcze przez media i modę intencja pozostawania przy swoim stanowisku, wykazania się i bycia tzw.

${ }^{28}$ H. Bon, Le dialogue et les dialogues, Toulouse 1910, s. 215.

${ }^{29}$ A. Mercatali, Introduzione alla pedagogia, Roma 1979, s. 126-127. 
„asertywnym” (z jakąś asertywnością posuniętą aż do form wręcz karykaturalnych $)^{30}$.

Do powyższego opisu możemy dołączyć opinię J. Deweya, który pisał: „Metoda dyskusji dla samego dyskutowania nie ma nic wspólnego chociażby z postępowaniem $\mathrm{w}$ innych zorganizowanych badaniach wspólnych, które doprowadziły m.in. do triumfu nauki w naukach przyrodniczych"31.

Aktualny kryzys, jakiego doświadczają współczesne rodziny i szkoły oraz inne instytucje, w świetle powyższych analiz wydaje się możliwy do przezwyciężenia, o ile te instytucje zdołają odzyskać wzajemne zaufanie w relacjach swoich członków i uczniów oraz przezwyciężą ograniczenia związane $\mathrm{z}$ indywidualizmem, powstającym zwykle w relacjach naznaczonych perspektywą tylko ekonomiczną.

Prawdziwy dialog może być bardzo owocny jedynie tam, gdzie podmioty tego dialogu wzajemnie się wspierają i respektują nawzajem. Bez tego klimatu dialog będzie się stawał monologiem, lub też, jak czasami się stwierdza, «dialogiem wśród głuchych». Takim określeniem dialogu z głuchymi określa się dyskusję, w której każdy pozostaje obwarowany na swojej pozycji niezdolnej do jakiegokolwiek zrozumienia innych, a powodem może być, jak się podaje: błąd nadawcy, błąd odbiorcy bądź błąd zrozumienia - gdy słowom innego lub nadawanym znakom przypisuje się całkowicie inne znaczenia $^{32}$. Tego właśnie rodzaju głuchota, zwłaszcza moralna, polegająca na tym, że człowiek współczesny nie chce słuchać i nie jest ciekawy myślenia innych, jest jednym z podstawowych grzechów człowieka współczesnego. Oczywiście dołącza się do tego - i to w niemałym stopniu zarozumiałość, pycha i niezdolność do krytycznego spojrzenia na własną postawę

W zakresie wychowania, a zwłaszcza w funkcjonowaniu szkoły, należy podkreślić znaczenie, jakie posiada dialog dla metodyki wychowania ${ }^{34}$. Ważną rolę w tym zakresie spełniają już nawet podstawowe formy dialogu.

Do podstawowych i najbardziej znanych form dialogu należą, zdaniem Janusza Tarnowskiego:

1) «dialog rzeczowy», którego przedmiotem jest wszystko, co nas otacza, czyli wszelkie dziedziny poznawcze;

2) «dialog personalny», mający na celu zjednoczenie osób, gdy partnerzy dialogu odsłaniają własną osobę z jej wewnętrznymi przeżyciami oraz trudem dążenia do Prawdy i Piękna;

${ }^{30}$ Tamże, s. 127.

${ }^{31}$ J. Dewey, Liberalismo e azione sociale, a cura di R. Cresti, Firenze, 1974, s. 99.

${ }^{32}$ P. Foulquié, Dictionnaire de la langue pédagogique, Paris 1991, s. 124-125.

${ }^{33}$ Tamże.

${ }^{34}$ L. Stefanini, La scuola del dialogo: interrogazione ed esame, "La Scuola Secondaria", 3 (1954), s. 4-17. 
3) «dialog egzystencjalny», oparty na całkowitym darze partnerów z ich egzystencji ${ }^{35}$, co jest wyrazem największej Miłości.

Uwarunkowania każdej z tych form dialogu są inne, stąd też w niektórych przypadkach nastapiło spłycenie znaczenia tego słowa i nadawanie samemu dialogowi wieloznaczności. W procesie wychowawczym, gdzie występuje relacja wychowawca-wychowanek, konieczne jest, aby dialog był tą metoda, dzięki której partnerzy dialogu poznają się, będą dążyli do wzajemnego zrozumienia oraz ewentualnego współdziałania. Sam stosunek wychowawczy jest bowiem stosunkiem czysto dialogicznym ${ }^{36}$.

Dialog zawiera elementy, które służą chrześcijańskiemu wychowaniu, a osoba dzięki treściom przejętym z filozofii egzystencjalizmu pozostaje nadal punktem oparcia w procesie wychowawczym.

Wprowadzenie do pedagogiki polskiej, między innymi również przez ks. J. Tarnowskiego, takich kategorii pedagogicznych jak: «autentyczność», «dialog», «zaangażowanie», «spotkanie» oraz połączenie ich z personalizmem pozwala nam stwierdzić na gruncie wychowania chrześcijańskiego, że zwraca się ono ku osobie ludzkiej, a kategorie te wyrażają się w procesie wychowania, który ma na celu potrójne zadanie, a mianowicie: wychować do autentyzmu, dialogu i zaangażowania.

\section{Dialog wychowawczy i jego realizacja}

W kontekście wychowania, a zwłaszcza w edukacji szkolnej, wskazuje się na znaczenie dialogu pod względem wspomnianych wyżej nowych inicjatyw w zakresie metodyki nauczania i wychowania - właśnie podejmowanych pod wpływem zastosowań dialogu. Z kolei postęp, zwłaszcza w zakresie psychologii różnic indywidualnych, jeszcze wydatniej ukazał w wychowaniu, rozumianym jako relacja między wychowankiem a wychowawca, rolę indywidualnego charakteru podmiotów tej relacji i ich wzajemną dynamikę. W tej relacji szczególnego znaczenia nabiera dialog między wychowawcą a wychowankiem.

Idea dialogu wychowawczego rodzi poważny problem relacji między autorytetem wychowawcy a odpowiedzialnością wychowanka, który możemy ująć jako problem relacji między wolnością a autorytetem. Jeśli zaś wychowanie polega na kształtowaniu osobowości wychowanka do zdolności wolnej akceptacji dobra, jaka zatem byłaby droga do osiagnięcia podobnego rezultatu bez zaprzeczania podstawowej zasadzie wychowania?

\footnotetext{
${ }^{35}$ J. Tarnowski, Dialogi pedagogiczne, t. 1: Trudne sprawy młodych, Warszawa, 1989, s. 7.

${ }^{36}$ Tenże, Wychowanie, „Znak” 4 (1968), s. 456.
} 
Podstawowe zadanie wychowania nie polega na przedstawianiu wychowankowi motywów, które przez ich wartość i ich wagę byłyby niepodważalne, lecz na wspieraniu podmiotu, aby potrafił wartościować i docenić samą wartość tych motywów, jakie zostaną mu zaproponowane w różnych sytuacjach życiowych, oraz dokonywania wyborów w oparciu o zasady moralne własnego sumienia. Jeśli natomiast podmiot zostanie uzdolniony jedynie do działania pod wpływem bodźców oczywistych, stałby się automatem, także przy realizowaniu wyższych funkcji psychicznych.

W koncepcji dialogu wychowawczego przezwyciężana jest taka koncepcja, według której tylko wychowawca wychowywałby, natomiast wychowanek byłby jedynie obiektem (przedmiotem) jego oddziaływań. Taka koncepcja jest dzięki praktyce dialogu przezwyciężana i zastapiona przez tę, którą określiliśmy wyżej, jako «otwartą i personalistyczna»», a mianowicie według której, wszyscy są wychowawcami i wychowankami, każdy na swój sposób (P. Freire).

Pozostawać zaś «otwartym» oznacza, że w dialogu cała nasza uwaga powinna być skierowana na innego a nie na nas samych. Przekłada się to również na konkretne posiadanie własnego spojrzenia i własnych ideałów i niekorzystanie ze zdania innych, gdy posiadamy na ten temat własną opinię czy argumentację $e^{37}$.

Wychowanie zakłada zatem podjęcie dialogu $\mathrm{z}$ wychowankami, poszukując wraz z nimi prawdy, w której wychowawca, bez utraty swojej tożsamości, dzieli się swoim doświadczeniem i swoją wiedzą z wychowankami, pozostając także otwartym i dyspozycyjnym na przyjęcie tego, co również uczniowie wnosza, i ubogacanie się ich wkładem. Wychowanie zakłada kształtowanie wychowanków do umiejętności dialogowania z osobami jako takimi, przyjmując je, respektując i wnosząc wkład do jej realizowania. To zaś kształcenie wychowanków obejmuje ponadto nabywanie przez nich coraz większej ilości dyspozycji zarówno tych ogólnych, jak i szczegółowych, włącznie z umiejętnością dialogu dotyczącego podstawowych idei i ideałów, wymiany własnych przekonań, własnej wiary i też w wychowaniu chrześcijańskim dialogu wiary i nauki oraz wiary i kultury ${ }^{38}$.

Przekłada się to także na konteksty epistemologii pedagogicznej. Istnieje permanentna potrzeba ustawicznego konfrontowania i uwzględniania w dialogu problemów dotyczących rozumienia rzeczywistości i sensu życia. Istnieją bowiem sytuacje, w których praktyczne (np. religijne, polityczne lub pedagogiczne) interesy zaczynają wypierać racjonalną argumentację, wpływając na tworzenie fałszywych teorii. Potrzebna jest więc zdolność ujmowania pojedynczych faktów w kontekście całej rzeczywistości. Tę zdolność

${ }^{37}$ H. Bon, dz. cyt., s. 215.

${ }^{38}$ L. A. Gallo, dz. cyt., s. 289. 
łączy się często z «mądrością». I w taki sposób nawiązujemy do etymologii słowa «filozofia», którą wyprowadza się z języka greckiego i rozumie jako «miłość do mądrości». W ujęciu filozoficznym ważne byłoby więc nie tyle «intelektualne opanowanie» rzeczywistości w celu lepszego dysponowania nią i «technicznego użycia», lecz jej racjonalne zgłębianie i poszukiwanie ostatecznego sensu. Nie umniejsza to praktycznego znaczenia filozofii: «prześwietlenie» poszczególnych badań naukowych w charakterystycznym dla niej aspekcie odpowiada ludzkiej potrzebie oglądu całości, ujęć globalnych i wydobywania sensu (często ostatecznego) ${ }^{39}$.

Zwłaszcza biorąc pod uwagę wychowanie chrześcijańskie, tym bardziej możemy podkreślić potrzebę kształtowania $\mathrm{w}$ wychowankach umiejętności dialogu z Bogiem i z samym sobą, ale także dialogu na zewnątrz: z osobami a wśród nich z także: niewierzącymi, z innymi religiami i kulturami, z wiedzą naukową i kulturą.

Istota dialogu wychowawczego wiąże się z relacją człowieka z człowiekiem, w której to relacji zacierają się różnice związane z wiekiem i rolami, natomiast budzi się sympatia i zainteresowanie, wzajemne komunikowanie i gotowość do uwzględnienia słów i perspektywy patrzenia drugiego, aż do zdolności patrzenia na rzeczy z pozycji drugiego.

Aby tego rodzaju warunki mogły zaistnieć, konieczna jest po stronie wychowanka postawa relaksu, która pozwala - dzięki pomocy ze strony drugiej osoby - na redukcję napięcia i usunie lęk wobec powstających trudności życia. Ten dialog o charakterze duchowym, związanym z kontaktem i wzajemnym zrozumieniem, wydaje się być podstawowym dla procesu wychowawczego. Wyniki w procesie wychowania nie będą nigdy bezpośrednie czy natychmiastowe ani też zawsze zadowalające, gdyż należałoby zwracać uwagę na uwarunkowania tego, co Augusto Baroni określa jako «ubogi egzystencjalnie człowiek»; lecz o skutkach można mówić, a wydają się one być te same, jak te proponowane w dialogu terapeutycznym, a mianowicie reorganizacja świata percepcji i rozwój zdolności samokontroli.

Dialog nakierowany na porozumienie i zrozumienie się między wychowawcą a wychowankiem posiada zaskakujący efekt, jakim jest dojście zarówno podmiotu - w odniesieniu do wychowanka, jak i tego podmiotu, jakim jest wychowawca, do nowego zrozumienia samego siebie i otaczającego świata. Jedno ze zdań, jakie spotykamy w psychoterapii, podkreśla, że pod koniec procesu terapeutycznego podmiot zwykle dochodzi do widzenia rzeczy w sposób odmienny. Nie jest to jakaś jedynie zwykła analogia w opisie zestawiającym psychoterapię z wychowaniem, lecz rzeczywista bliskość

${ }^{39}$ Zob. M. A. Krapiec, Koncepcje nauki i filozofia, w: tenże (i in.), Wprowadzenie do filozofii, Lublin 1992, s. 17-33; H. Beck (Hrsg.) Philosophie der Erziehung, s. 12-13. 
obu procesów, w których chodziłoby o prawdziwą reorganizację świata percepcji jednostki, a którego znaczenie jest bardzo istotne zarówno dla terapii, jak i dla wychowania.

Podczas dialogu można być dogłębnie dotkniętym pewnymi stwierdzeniami wypowiadanymi, które wydają się wskazywać na pewną percepcję opartą zwłaszcza na wrażeniach i bodźcach wzrokowych, które podlegają głębokim przemianom. W treści wywiadów terapeutycznych są niejednokrotnie takie komentarze, które wskazują, że osoby i rzeczy znajdujące się wokół oraz cały świat zewnętrzny są widziane na sposób odmienny niż to ma miejsce w relacji do procesu terapeutycznego. Czasami zmiana w percepcji otoczenia jest rzeczywiście bardzo głęboka lub nawet wręcz dramatyczna.

Jak potwierdzają to badania naukowe, akceptacja innych, uczucia w odniesieniu do innych, są w pozytywnej relacji ze stopniem akceptacji, z charakterem własnych przeżyć i percepcją samego siebie. I tak jak psychoterapia może wywoływać zmiany w percepcji samego siebie, tak również wychowanie oparte na prawdziwym dialogu takie zmiany może powodować. W wychowaniu jest nieodzowna ciagła reorganizacja świata poznawanego przez wychowanka, gdyż jego osobowość jest poddana ewolucyjnemu rozwojowi i podlega $\mathrm{w}$ rezultacie głębokim przemianom. I to właśnie tego rodzaju reorganizacja własnej percepcji, nastawiona na obudzenie w jednostce uczuć i postaw o charakterze pozytywnym, stanowi już w samym sobie ważny element pedagogiczny o wielkim znaczeniu ${ }^{40}$.

Na zakończenie warto wskazać przynajmniej na implikacje dialogu także dla samego uprawiania pedagogiki jako nauki. Podejmując wątek charakterystyki pedagogiki jako nauki spekulatywno-filozoficznej i empirycznopraktycznej, w przypadku tej ostatniej możemy wskazać na teorię i praktykę prowadzenia dialogu, rozwijaną począwszy od Platona, poprzez Schleiermachera aż do naszych czasów. W aspekcie zaś spekulatywno-filozoficznym możemy przywołać zwłaszcza «filozofię dialogu» opracowaną i ukierunkowaną pedagogicznie przez jej twórcę, Martina Bubera.

Na ile zatem «praktyka» implikuje tworzenie wiedzy pedagogicznej, na tyle również «praktyka dialogu» ją implikuje w myśl zasady: praktyka rodzi problemy, a rozwiązuje je «teoria», ale także i odwrotnie: teoria stawia hipotezy, a praktyka je potwierdza, weryfikuje i sprawdza. Widzimy to zwłaszcza w kontekście dialogu interdyscyplinarnego w pedagogice. Dialog taki wymaga, aby każda z nauk biorących w nim udział określiła dokładnie własny przedmiot/obszar swoich zainteresowań, jak również specyficzne metody oraz organizację i przebieg badań, w jakich chcą uczestniczyć.

By jednak dialog przeszedł z fazy komunikowania w fazę efektywnej

${ }^{40}$ A. Mercatali, dz. cyt., s. 127-129. 
współpracy, niezbędny jest jeszcze jeden warunek: stworzenie wytworów badań, kategorii i koncepcji, które stawałyby się możliwe do użycia także przez inną dyscyplinę. Wymagałoby to rzeczywistej reformy systemu wiedzy poszczególnych dyscyplin, niejednokrotnie hołdujących jakimś stereotypom, teoriom, do których się przyzwyczaiły i w których czują się już ekspertami, jak w starych butach ich właściciel.

\section{Dialogue in education (Summary)}

This paper analyses the phenomenon of dialogue that is in close relationship with the process of education and in this context we seek its meaning and role. Starting from the etymology of the word 'dialogue', we indicate here some basic problems related with dialogue, its nature and its relationship with education. Education calls for dialogue because of tis spiritual character and nature. The analysis of the basic elements that compose the structure of dialogue allows us to list its varieties and its implications for education and teaching and for pedagogy itself as a science. An authentic dialogue requires many attitudes, internal inclinations and skills. It is the leaving of person's 'I' from himself through speech (by way of words or gestures) and tending toward the second 'you' in which we offer ourselves to another, and we also accept his word and open ourselves to his most intimate sphere.

According to J. Tarnowski, dialogue is a process through which two subjects, with the use of words, reconcile their points of view and their ways of life. Dialogue understood in this manner is a method, process, and attitude and it may be fruitful only there where its subjects support and respect each other. Without this climate, dialogue would remain monologue or else, as it happens at times, dialogue between the deaf people. According to Janusz Tarnowski, the basic forms of dialogue are the following: 1) substantial dialogue, its subject matter being everything that surrounds us, that is, any spheres of knowledge; 2) personal dialogue, that tends to unite persons when its partners reveal themselves with their internal experiences and their drive towards the Truth and Beauty; 3) existential dialogue is based on a complete gift that the partners offer of their existence, the gift that is a token of the ultimate Love.

Education to dialogue presupposes the shaping of pupils to be able to enter into a dialogue with other persons as such, to accept and respect them, and to contribute to their humankind. The essence of educational dialogue is connected with the relationship between one person and another person. In this relationship, the differences related to age and role become blurred. It arouses sympathy and mutual interest, mutual communication and a readiness to take into consideration the other person's words and viewpoints, until one is able to look at the world around from the position of another person. 
